\title{
18. タイの沿岸環境問題と気候変動の影響 \\ Coastal Environmental Problems and Impacts of Climate Change in Thailand
}

\author{
三村信男*・加藤貴子**・横木裕宗* \\ Nobuo MIMURA, Takako KATO, Hiromune YOKOKI
}

\begin{abstract}
Developing countries in the Asian and Pacific region are anticipated to face serious impacts of climate change, because of not only their geographic settings but also the high growth of population and economy. Many countries have tried to identify the specific impacts on them without success. The major reason for this is lack of data. Thailand is a country which accumulates relatively large amount of data including GIS database. This study aims at correlating the existing coastal problems with the impacts of climate change and sea-level rise, based on review of the impact studies and new analysis using the databases developed both in Thailand and in the world. Sea-level rise and climate change would significantly exacerbate existing coastal problems, such as coastal erosion and retreat of mangrove forest. In particular, mangrove forests in Thailand is the case, for they have already been experiencing strong pressures due to land subsidence and clearing for shrimp ponds. The threats of the storm surge and flooding are another concern in the Central Plain, the Chao Phraya Delta, where Bangkok is situated.
\end{abstract}

KEYWORDS: coastal environment, erosion, mangrove, climate change, Thailand

\section{1. 研究の目的}

地球温暖化による気候変動・海面上昇の影響は、アジア・太平洋地域で顕著に現れると指摘されてきた。 気候変動による自然生態系の破壊や社会経済的損失が懸念されており、海面上昇や地盤沈下による水没と 高潮による汇濫頻度の増加があいまって沿岸域に相当の被害をもたらすと予想される。特にこの地域の途. 上国では、今後、人口増加や経済成長が見込まれるために、これらの影響が一層重要になる。また、マン グローブやサンゴ礁で縁取られた海岸線の応答は、それ自体地形学的な研究の対象になっている。しかし、 多くの途上国では基礎的なデータが少ないことをはじめ、影響評価には様々な障害が残されている。

タイは、東南アジアの途上国では比較的よくデータが整っている国の1つである。また、わが国の研究 者との交流の蓄積もあってデータが入手しやすい。ここ数年、気候変動の影響に関する研究が取り組まれ ており、1997年からはこの課題で両国の共同研究が行われた（建設省国土地理院ほか、2000）。また、タ イ全土の地理的、社会的データをディジタル化したGISデータベースが発行された。このようにして、タイ ではより体系的な影響評価の条件が向上しつつあると考えられる。本論では、GISデータベースを利用して 気候変動・海面上昇の影響を推定し、タイ沿岸域の現在の環境問題とどのような関係があるかを検討する。

\section{2. タイの地理・気候の概要}

タイはインドシナ半島の南部に位置している。タイの中央部にはピング、ヨング、ヨム、ナン川の4大支 川が南下してタイの最大水系となるチャオプラヤ川となりタイ湾に注いでいる。西方にはメクロン川が流

*茨城大学広域水圈環境科学教育研究センターCenter for Water Environment Studies, Ibaraki University

**茨城大学大学院理工学研究科 Dept. of Urban and Civil Eng., Graduate School of Eng., Ibaraki University 


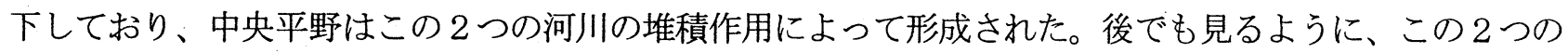
河川の土砂輸送が沿岸域の環境に大きな影響をもたらす。

タイ国土の大部分で年間降水量が $1200 \mathrm{~mm}$ を越え、南部は年間降水量 $2000 \mathrm{~mm}$ 越える熱帯気候である。 最大の気象外力はモンスーンである。3月から10月にかけての南西モンスーンと10月から2月にかけての北 東モンスーンの2大モンスーンの交代があり、それぞれ雨期と乾期に対応している。サイクロンの来襲頻度 は小さいが、10～11月にかけてはサイクロンがタイ湾を横断することがある。沿岸部は、サイクロンとモ ンスーンの方向に応じて卓越方向の異なる波の作用を受けることになる(Vongvisessomjai, 1994a,b)。

タイ湾沿いの沿岸部は、1980年代以降、開発計画が進められている。タイ湾東岸やマレー半島の南部で は、天然ガスや石油の分離・精製などの工業開発と港湾の建設が進められ、また、各地で観光開発のため のリゾート建設が進められた。こうした人為的な作用が、海岸侵食や水質污濁をもたらしているという指 摘がある(Wesakul, 1992)。

\section{3. 沿岸環境問題}

タイにおける沿岸環境問題については、様々な角度からの報告がある。ここでは、従来の研究結果や現 地踏査に基づいて、特に気候変動、海面上昇の影響と関係が深い問題を中心に紹介する。

3.1 海岸侵食 (Vongvisessomjai, 1992; Wesakul, 1992)

タイにおける海岸侵食には、大きく砂浜とマ ングローブなどの湿地帯・泥浜の侵食がある。 マングローブの問題は次の項で扱うとして、こ こでは、砂浜の侵食の状況をみる。

タイでは、マレー半島に広く砂浜が分布して おり、東側（タイ湾沿岸）と西側（アンダマン 海沿岸）両方で海岸侵食問題が生じている。マ レー半島東側では、モンスーンの風向の変化に 応じて沿岸漂砂の方向も南北に交代する。近年、 いくつかの地点で激しい侵食が発生しており、 多くの場合、住民は割石などを投入して、初歩 的な対応をしている（写真1）。地形変化の原因 の 1 つは、漁港の防波堤や河口導流堤の建設に よって沿岸漂砂が遮断されるためであり、防波 堤や突堤が建設された地点では、上手側で堆積、 下手側で侵食という典型的なパターンがみられ る。漂砂源の情報が入手できなかったために、 大局的な土砂収支の変化は確認できなかった。 侵食の激化に対して、一部では、離岸堤とマン グローブの植林を組み合わせた対策や護岸の建 設が行われている。写真2は、マレー半島東岸の Phechaburi付近の海岸の例で、海岸線にマング ローブの帯を形成することで安定化が図られて いる。しかし、このような対策がとられている 地点はまだ少ない。

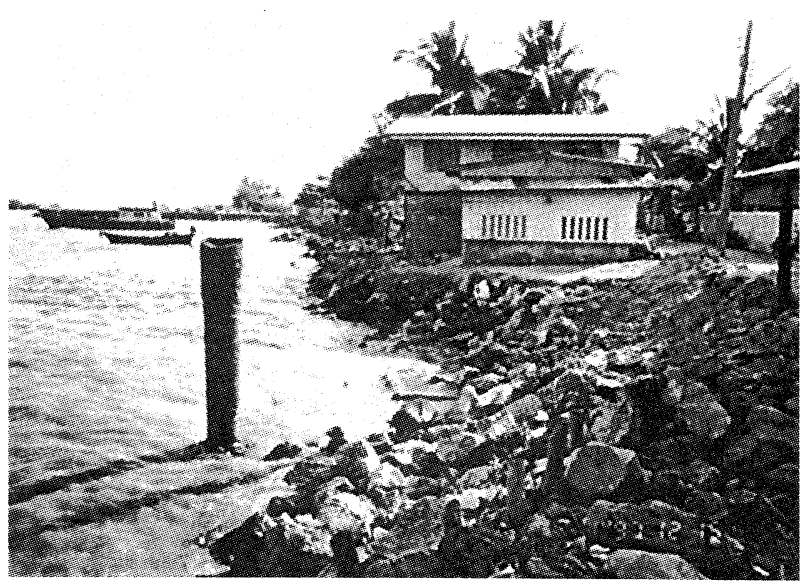

写真1 マレー半島東側Phechaburi付近の侵食

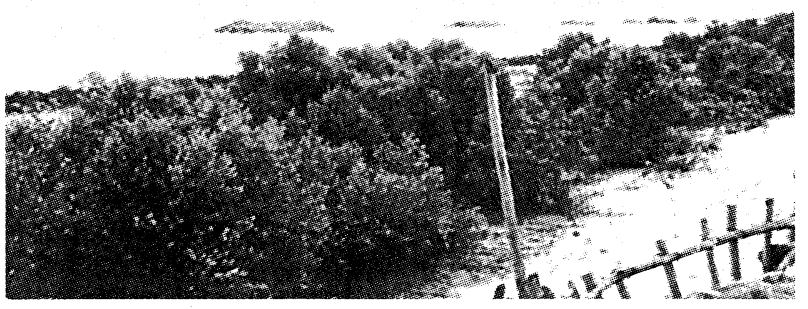

写真2 離岸堤とマングローブ植林を組み合わせた防護 
3.2 マングローブ林の侵食と伐採(Somboon and N.Thiramongkol,1993; 建設省国土地理院 ほか, 2000)

タイの海岸線を特徵付けるマングローブは、 タイ湾沿岸やマレー半島の海岸線に広く分布す る。タイ中央平野では、チャオプラヤ川とメク ロン川が供給する約2千万トン／年の土砂によっ てデルタが形成され、6〜 5千年前の最大海進期 （温暖期）以降海岸線が前進してきた。デルタ 前面がマングローブ林で覆われており、とりわ け、タイ湾奥では幅が5〜 10kmに及ぶマング ローブ林が広がっているが、近年このマング ローブ林の後退が問題になっている。チャオプ ラヤ川河口の西側の海岸（延長29.5km）では、 1969年から1987年の 18 年間に最大 $700 \mathrm{~m}$ ものン グローブの後退が生じたと報告されている。現 地では、海中に電柱が取り残されており、最前 面のマングローブが茶色に変色して、後退速度 は小さくなったということであるが、まだ後退 が続いているように見える（写真3）。

こうしたマングローブの後退にもっとも影響 の大きいのは、地盤沈下であると推測されてい る。バンコク周辺では、大量の地下水汲み上げ によって、著しい地盤沈下が生じた（図1）。

その影響は、1978年から1987年までの 9 年間で、 $250 \mathrm{~km}^{2}$ の地域に及び、沈下量は最大で $160 \mathrm{~cm} に$ 達している。マングローブは、もともと平均潮 位と満潮位の間に生育するため、沈下によって 地盤高が低下寸れば生息域が狭まる。また、 チャオプラヤ川、メクロン川の上流にダムが建 設されて土砂供給量が減少したため、地盤沈下 を補償する土砂量が不足することになる。これ らの要因が重なって、マングローブ林の激しい 後退が生じたものと考えられる。こうした因果 関係は、将来の海面上昇の影響を予測する上で、 きわめて示唆的といえる。

マングローブ林への影響要因としてもう $1 つ$ 重要なのは、人為的な伐採である。過去 20 年間 広大な面積のマングローブ林が伐採され、エビ や魚の養殖場に転換されてきた。しかし、過密 な盖殖によって、エサとなるプランクトンを育 てる底泥中の栄養塩を消費し、病気の発生も

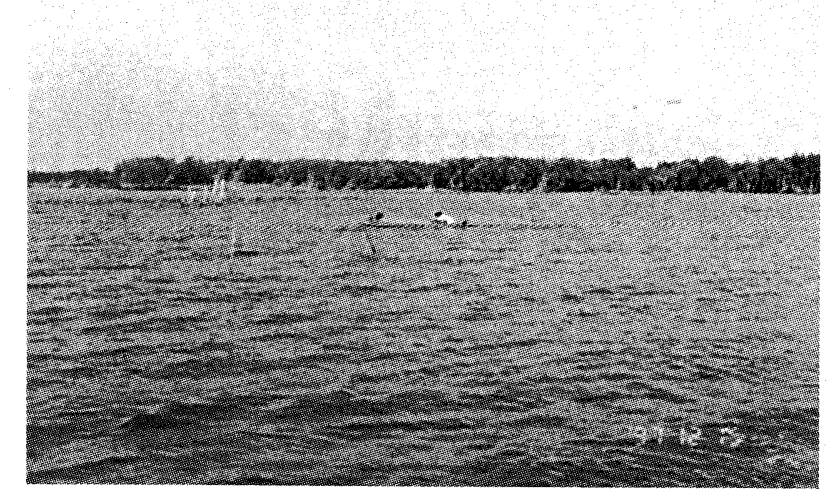

写真3 後退したマリグローブ林（チ切プ河口西側）

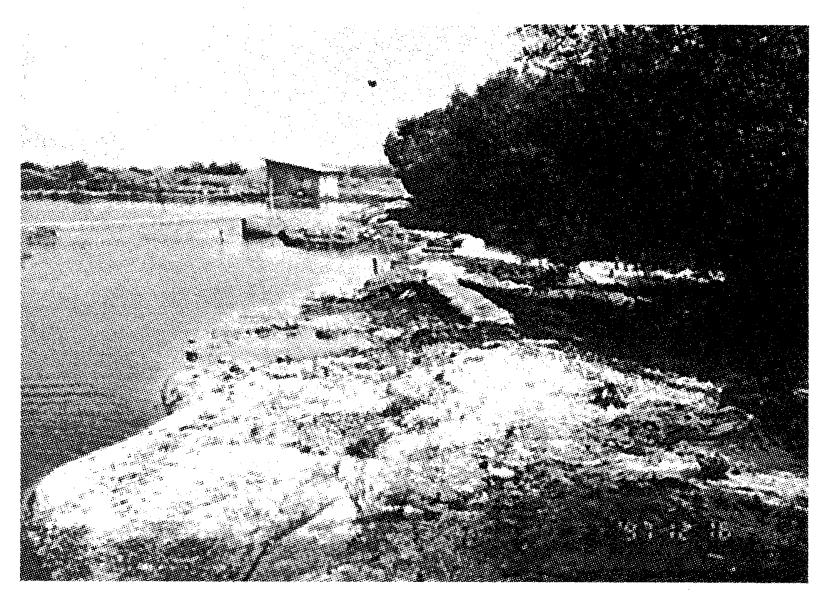

写真4 廃棄されたエビの養殖池

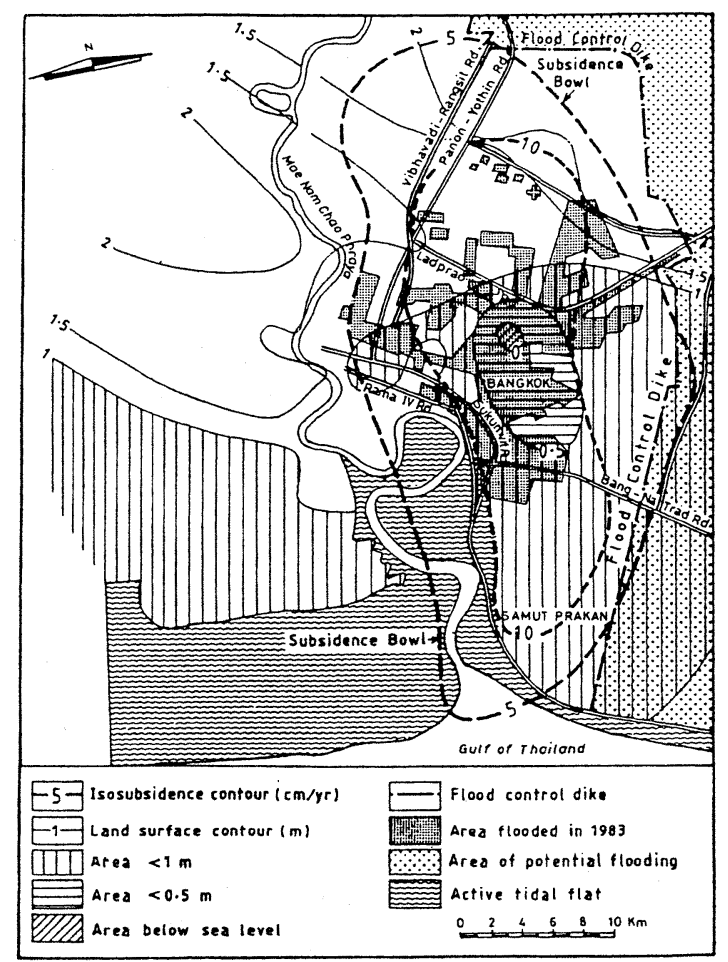

図1 バンコク周辺の地盤沈下の分布 
あって、数年で放棄される例が多い（写真4）。一部は塩田などに転用されているが、多くはそのまま放置 されており、前面のマングローブの侵食が養殖池に届けば、消波機能を果たすものがないために一挙に侵 食が進むおそれもある。

\section{3 塩水の侵入 (Arunin, 1999)}

タイの中央平野はきわめて平坦で、勾配は $1 / 30,000$ 程度である。そのため、排水不良を起こしやすく、氾

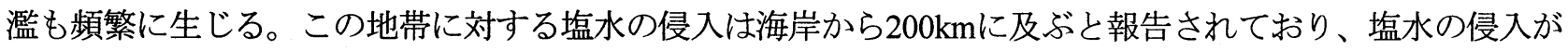
さらに進行すると、それを排除する淡水量が不足すると指摘されている。この地帯は、タイの中心的な米 作地帯で、全国の収穫量の約 $40 \%$ 生産している。そのため、地下水の塩水化や塩水侵入の激化は、米作 に対する劦威として強く認識されている。

\section{4. 気候変動・海面上昇の影響}

\section{1 影響評価の方法とデータ}

沿岸域に影響を及ぼす気候変動 の最大要因は、海面上昇とサイク ロンによる高潮である。そこで、 これらに伴う水没域と汇濫域を特 定し、その結果、人口や土地利用 などの社会的条件と自然環境にど のような影響が生じるかを検討し た。海面水

位の将来シナリオには、潮汐の水 位と海面上昇を考慮し、海面上昇 量としては今後 100 年間に $1 \mathrm{~m}$ とい う值をとった。過去 40 年間のサイ クロンによる高潮を推算し、過去 の傾向が変わらないと仮定して、 最大の高潮偏差を氾濫水位に設定 した。高潮の推算を含むこうした 方法は、三村ら(2000)と同じであ り、そちらに述べられている。

影響域内の社会・自然環境要素 については、タイ環境研究所が作 成した「Thailand on a Disc」とい うディジタルデータベースを利用 した。このデータベースは、基本 的には $1 / 25$ 万の精度で、中央部、 東部、北東部、北部、南部の5つ の地域に分割してタイ全土をカ バーしている。データ項目は、行 政区域、農業、環境、森林、地質、 インフラ施設、社会経済、地形、

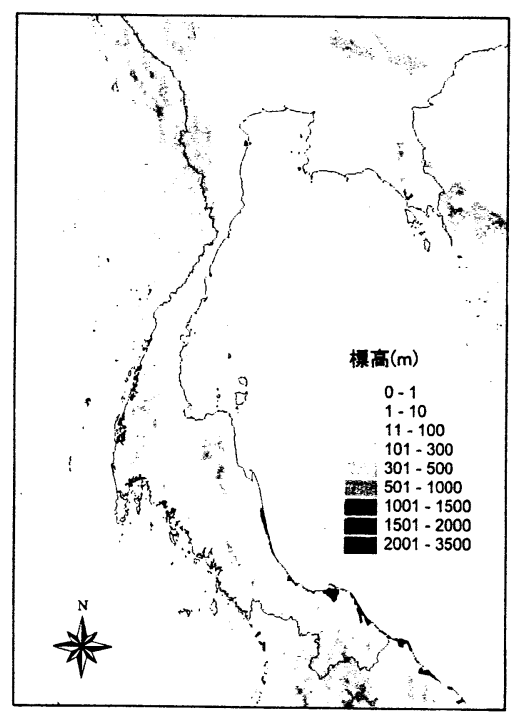

(a) 満潮十海面上昇 $(1 \mathrm{~m})$

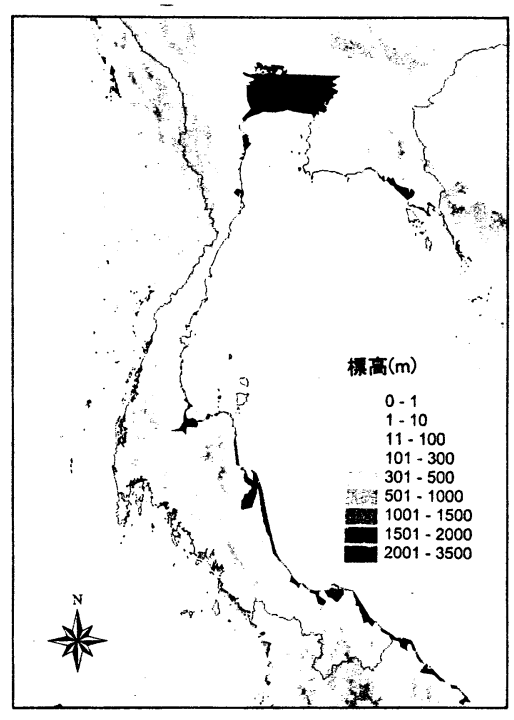

(b) 満潮十海面上昇 $(1 \mathrm{~m})$ +高潮

図2 水没及び氾濫域の分布

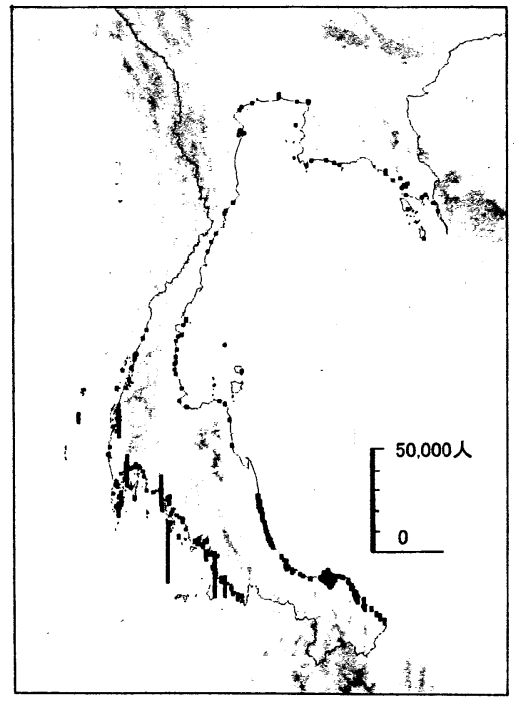

(a) 満潮十海面上昇 $(1 \mathrm{~m})$

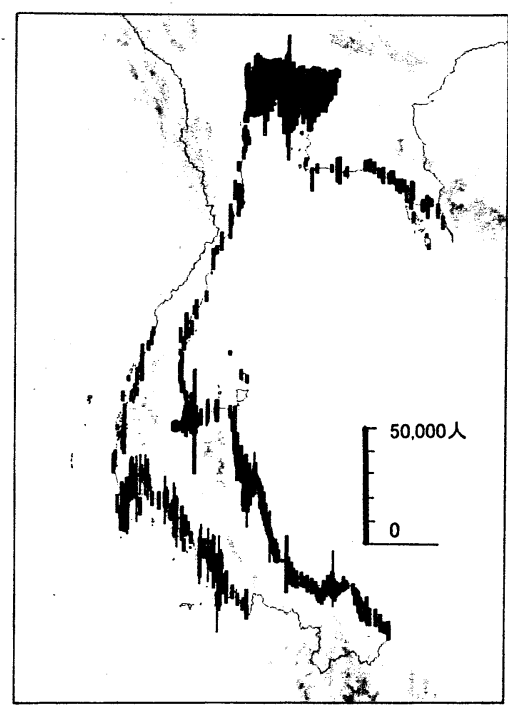

(b) 満潮十海面上昇 $(1 \mathrm{~m})$ +高潮

図3 影響人口の分布 
水域の9つに分類されており、その下に多 数の要素データが与えられている。人口 等の社会要素の多くは、タンボン（町あ るいは集落）という行政の基本単位に基 づいて整理されているため、影響評価に おいてもタンボン毎に評価し、タンボン の一部が影響域にかかる場合は、面積に 応じて影響量を案分した。

\section{2 海面上昇と高潮による影響}

(1) 影響面積

$1 \mathrm{~m}$ の海面上昇による水没面積と高潮の 氾濫面積を図2(a)，(b)に示す。海面上昇に よる水没面積は約 $2,400 \mathrm{~km}^{2}$ となる。これは タイ全土の面積約 51.3 万 $\mathrm{km}^{2}$ の $0.47 \%$ にあ たる。全国的には水没面積は少ないが、 マレー半島南部のパタニ地方やアンダマ ン海側に比較的広くみられる。

高潮の氾濫面積は $12,000 \mathrm{~km}^{2}$ でタイ全土 の $2 \%$ となった。単純な水没と比べると浸 水域は約5倍に広がる。そのうち約6割が 首都バンコクを含むチャオプラヤデルタ 域に存在し、高潮の影響はタイ湾沿岸に 顕著に現れる傾向がある。

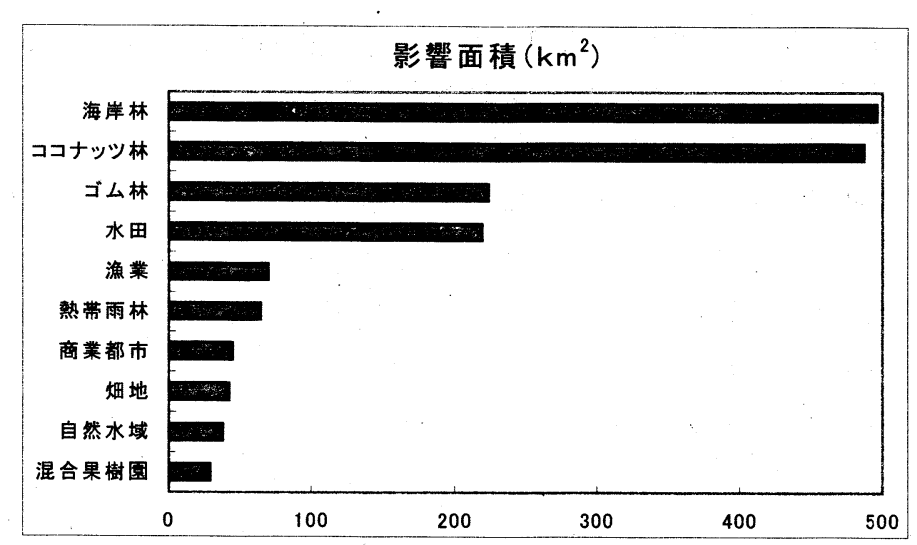

図4 海面上昇の影響を受ける土地利用

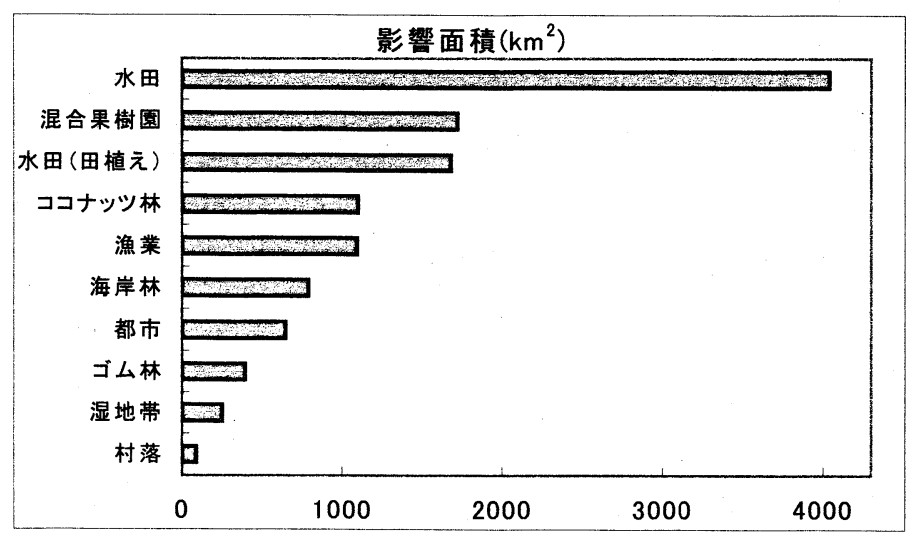

図5 海面上昇十高潮の影響を受ける土地利用

(2) 社会・土地利用一の影響

$1 \mathrm{~m}$ 海面上昇によって水没の危険にさらされる人口は約33万人という結果になった。比較的影響人口の 多い地域はアンダマン海側にみられる（図3(a)）。これに対して、高潮の影響人口は約390万人と単純な水 没と比較して10倍以上になる（図3(b)）。しかも、影響を受ける909タンボンのうち、157タンボンの人口 データが不明であり、そのほとんどが中央平野の都市部にあるため、実際にはさらに多くの人が高潮の危 険にさらされることになる。

次に、土地利用区分において、1mの海面上昇による水没域と高潮の汇濫域の中で影響面積の多いものを図4, 5に示す。海面上昇の影響がもっとも大きいのは海岸林で（影響面積は約 $500 \mathrm{~km}^{2}$ ）、これは海岸がマング ローブでおおわれているいることを反映している。一方、高潮の氾監域では、水田が圧倒的になり、その 他に果樹園、ココナッツ林といった農業的な土地利用が大部分を占めるようになる。この他に、沿岸部の 交通・インフラ施設についても検討したが、一部の鉄道路線が海面上昇の影響域にあるのみで、交通施設 はやや内陸よりに建設されているようである。

(3) 湿地帯への影響

タイにおいて海面上昇により影響を受ける湿地帯の面積は約 $300 \mathrm{~km}^{2}$ である。そのうち一番影響面積の大 きい湿地帯はKrabi湾に存在し、約70 $\mathrm{km}^{2}$ が影響範囲に含まれる。高潮により影響を受ける湿地帯の面積は 約 $6000 \mathrm{~km}^{2}$ と単純な水没に比べ約20倍になる。なかでも中央平野南部で約 $5000 \mathrm{~km}$ き湿地帯の影響のほとん どを占めている。 


\section{5. おわりに一現在の問題と気候変動の関係}

タイにおいて予想される気候変動・海面上昇の影響は、現在の問題と強い関連があるのが認識できる。 タイの沿岸域では、海岸侵食やマングローブ林の後退・劣化、塩水の侵入などが生じている。将来、海面 上昇やサイクロンによる高潮が生じると、これらの問題の深刻化が一層加速されることになろう(Jarupongsal, 1999)。特に、マングローブ林は平均海面と満潮位との間に生息するという性質から、相対的な海面変動の 影響を受けやすい。そのため、地盤沈下や流送土砂の減少といった人為的な要因によって生じる後退が、 海面上昇によって一層大きくなると考えられる。こうしたマングローブの生育特性からすると、相対的海 面上昇の影響は潮差の小さい地点ほど大きく現れることになる。

タイの社会的な影響は、高潮まで考慮すれば、中央平野及びマレー半島の地方中心都市で大きいことが わかる。特に、中央平野には、首都バンコクが位置し、周辺にも人口が集中した都市が多い。これらの地 域では、従来から、雨期の洪水に見舞われてきた。現状でも、支流が合流してチャオプラヤ川となる中流 部で、氾濫が頻発し、長期化している(ESCAP,1998)。河川の氾濫は、今回の検討には取り込めなかったが、 海面上昇と高潮が重なると、沿岸部の低地帯では両者を併せた氾濫危険地帯が大きく広がることが分かる。

これまで、現在の環境問題や自然災害問題と将来の地球環境変動の影響とは、切り離されて議論される 傾向が強かったように感じる。しかし、本論で示したように、両者は「連続」しており、現在の問題が気 候変動・海面上昇によって増幅されるところに影響の本質的な一面がある。このことは、気候変動への適 応策を検討する際にも、現在の問題への対応を十分考えることからスタートすべきことを示唆していよう。

\section{参考文献}

建設省国土地理院ほか(2000) : 環境庁地球環境研究総合推進費終了報告書「海面上昇の影響の総合評価に関 する研究 平成 9 年度〜平成 11 年度」, 99 p.

三村信男・佐藤圭輔・大高京子・横木裕宗(2000) : 地球環境情報を用いたアジア・太平洋地域に対する海面 上昇の影響評価、第8回地球環境ジポ ジウム講演論文集.

Arunin, S.(1999): Impacts of sea-level rise on coastal areas of Thailand, highlighting on agriculture, Current Topics in Wetland Biogeochemistry, Vol.3, pp.143-151.

ESCAP(1998): Development and achievements in flood control and management in Thailand- A case study, National Experience of Flood Control and Management for Improvement of the Urban Environment in the Region, 49p. with an Annex.

Sumboun, J.R.P. and N.Thiramongkol(1993): Effects of sea-level rise on the North Coast of the Bight of Bangkok, Thailand, Malaysia Journal of Tropical Geography, Vol.24(1/2), pp.3-12.

Jarupongsal, T.(1999): The impacts of se-level rise and flooding for the Gulf of Thailand and Region, personal report, pp.97-158.

Vongvisessomjai, S.(1992): Coastal development and coastal environment problems in Thailand, in:Shibayama, T.(ed.), Coastal Processes in Asian Region, Yokohama National University, pp.63-92. Vongvisessomjai, S.(1994a): Cyclone disasters in Southern Thailand due to heavy rainfall, Research and Development Journal of the Engineering Institute of Thailand, Vol.5,No.1, pp.113-128.

Vongvisessomjai, S.(1994b): Cyclone diasters in Thailand due to strong wind and surge, Research and Development Journal of the Engineering Institute of Thailand, Vol.5, No.2, pp.34-46.

Wesakul, S.(1992): Navigation channels improvement in Southern Part of Thailand, in:Shibayama, T.(ed.), Coastal Processes in Asian Region, Yokohama National University, pp.155-174. 